\title{
Produktivitas Tenaga Kerja Pertanian dan Industri Pengolahan: Lesson Learned Pandemi Covid-19
}

\author{
Deltha Airuzsh Lubis ${ }^{\text {a }}$ \\ abadan Pusat Statistik (BPS) Provinsi Sumatera Utara, deltha@bps.go.id
}

\begin{abstract}
A b s t r a k
Produktivitas tenaga kerja merupakan salah satu agenda prioritas pemerintah dalam upaya meningkatkan daya saing nasional, khususnya di masa pandemi Covid-19 yang telah berefek ke berbagai aktivitas ekonomi di berbagai sektor. Penelitian ini bertujuan untuk mengidentifikasi produktivitas tenaga kerja beradasrkan sektor pertanian dan industri pengolahan di Sumatera Utara periode sebelum dan saat pandemi Covid-19 dan menganalisis faktor-faktor yang memengaruhinya. Faktor penentunya diantaranya adalah dimensi kesehatan dengan proksi Angka Harapan Hidup (AHH), dimensi Pendidikan dengan proksi Rata-rata Lama Sekolah (RLS), pembangunan fisik dengan proksi Pembentukan Modal Tetap Bruto (PMTB), dan Upah Minimum Kabupaten/Kota (UMK). Hasil identifikasi menunjukkan bahwa produktivitas tenaga kerja sektor pertanian tertinggi berada di Kota Sibolga dan produktivitas tenaga kerja sektor industri pengolahan berada di Kabupaten Labuhan Batu Selatan. Berdasarkan hasil analisis regresi multivariat, RLS dan UMK memiliki pengaruh positif dan signifikan terhadap produktivitas tenaga kerja di sektor pertanian sedangkan variabel dummy kondisi pandemik berpengaruh negatif dan signifikan. Sementara itu, PMTB dan AHH tidak signifikan secara statistik pengaruhnya terhadap produktivitas tenaga kerja di sektor pertanian. RLS, PMTB, dan UMK berpengaruh positif terhadap produktivitas tenaga kerja di sektor industri pengolahan sedangkan variabel dummy kondisi pandemi berpengaruh negatif dan signifikan. Sementara itu, AHH tidak signifikan secara statistik pengaruhnya terhadap produktivitas tenaga kerja di sektor industri pengolahan di Sumatera Utara. Berdasarkan nilai eta square lambda sebesar 0,756 menunjukkan bahwa keragaman model dapat dijelaskan oleh variabel RLS, AHH, PMTB, UMK, dan variabel dummy kondisi pandemi sebesar 75,6 persen dan sisanya sebesar 24,4 persen dijelaskan oleh variabel lain di luar model.
\end{abstract}

Kata Kunci: Agrikultur, Covid-19, Industri Pengolahan, Multivariat, Pandemi, Pertanian, Produktivitas, Sektoral, Tenaga Kerja.

\section{A b s t r a c t}

Labour productivity is one of the government's priority agendas to increase the nation's competitiveness, especially since the COVID-19 pandemic affects the limited activities of the general public in various sectors. This study aims to identify labor productivity by sector (Agriculture and Processing Industries) in Sumatera Utara before and during the COVID-19 pandemic and analyze the factors that influence it sectorally. The determination is made through the health dimension with the Life Expectancy $(A H H)$ approach, the education dimension with the Average Length of School (RLS) education, physical capital with the Gross Fixed Capital Formation (PMTB) approach, and the Regency/City Minimum Wage (UMK). The identification results show that the highest agricultural labor productivity is in Sibolga City, for the processing industry business field is in Labuhan Batu Selatan. Based on multivariate regression analysis, $R L S$ and UMK positively affect the productivity level of agricultural labor in Sumatera Utara, while pandemic conditions have a negative effect. Meanwhile, PMTB and AHH have no significant impact on the productivity level of agricultural labor in Sumatra Utara. RLS, PMTB, and UMK positively affect the productivity level of the manufacturing industry in Sumatera Utara, while pandemic conditions have a negative effect. Meanwhile, AHH has no significant impact on labor productivity in the manufacturing industry in Sumatra Utara. Based on the eta square lambda value of 0.756, the variability of the response model can be explained by the RLS, AHH, 
PMTB, UMK, and pandemic dummy variables by 75.6 percent. In comparison, the remaining 24.4 percent is explained by other predictor variables outside.

Keywords: Agriculture, Covid-19, Labour, Manufacture, Multivariate, Pandemic, Productivity, Sectoral.

\section{Pendahuluan}

Tenaga kerja menjadi salah satu faktor produksi yang berperan penting pada siklus ekonomi suatu wilayah. Saat ini produktivitas tenaga kerja juga menjadi salah satu program prioritas pemerintah dalam rangka meningkatkan daya saing bangsa baik dari sisi daya tarik investasi maupun keunggulan produk barang dan jasa yang dihasilkan. Produktivitas yang baik menjadi salah satu pertimbangan investor untuk menanamkan modalnya ke dalam negri karena ongkos produksinya dianggap akan semakin efisien. Investasi tersebut juga menjadi roda penggerak dalam pembangunan wilayah, menyerap tenaga kerja, meningkatkan kualitas manusia, dan bermuara pada semakin meningkatnya kesejahteraan masyarakat. Tambunan menyebutkan bahwa investasi merupakan faktor krusial bagi kelangsungan proses pertumbuhan ekonomi dalam jangka panjang karena turut menciptakan lapangan kerja dan pendapatan masyarakat (Hellen et al., 2018).

Selain sebagai daya tarik investor, produktivitas kerja juga erat hubungannya dengan kemiskinan. Arndt dan Sundrum menyebutkan bahwa kemiskinan di sebagian besar masyarakat Indonesia disebabkan oleh rendahnya produktivitas (Trisnu \& Sudiana, 2019). Produktivitas yang rendah merupakan efek dari rendahnya kualitas hidup baik dari sisi pendidikan, kesehatan, maupun penghasilan. Menurut data rilis ILO, produktivitas tenaga kerja Indonesia masih cukup rendah yaitu berada diurutan ke-107, bahkan berada dibawah beberapa negara ASEAN lainnya seperti Singapura, Malaysia, dan Thailand (ILO, 2021).

Kondisi pandemi covid-19 juga menjadi tantangan baru bagi isu produktivitas tenaga kerja di Indonesia. Kondisi pandemi telah menyebabkan terjadinya berbagai permasalahan sosial ekonomi seperti pada beberapa indikator yang dirilis oleh BPS, diantaranya terjadinya kontraksi ekonomi nasional pada tahun 2020 sebesar -2,07 persen (c-to-c), pengangguran bertambah menjadi 7,07 persen di Agustus 2020, serta meningkatnya penduduk miskin menjadi 9,78 persen pada Maret 2020 dan 10,19 persen pada September 2020 (BPS, 2021). Permasalahan tersebut tak hanya terjadi pada skala nasional namun hingga level daerah, seperti Sumatera Utara yang memiliki kontribusi pada perekonomian nasional sekitar 5,26 persen di tahun 2020 atau berada pada urutan kelima setelah DKI Jakarta, Jawa Timur, Jawa Barat, dan Jawa Tengah. Kondisi ketenagakerjaan di Sumatera Utara selama pandemi juga mengalami guncangan yang ditunjukkan oleh indikator tingkat pengangguran terbuka (TPT) seperti yang disajikan pada Tabel 1 berikut.

\section{Tabel 1}

Tingkat Pengangguran Terbuka (TPT) di Sumatera Utara (persen)

\begin{tabular}{|c|c|c|c|}
\hline \multirow{2}{*}{ Periode } & \multicolumn{3}{|c|}{ Tingkat Pengangguran Terbuka (\%) } \\
\cline { 2 - 4 } & Wilayah Perkotaan & Wilayah Perdesaan & Total \\
\hline Februari 2020 & 6,72 & 2,34 & 4,71 \\
\hline
\end{tabular}




\begin{tabular}{|c|c|c|c|}
\hline \multirow{2}{*}{ Periode } & \multicolumn{3}{|c|}{ Tingkat Pengangguran Terbuka (\%) } \\
\cline { 2 - 4 } & Wilayah Perkotaan & Wilayah Perdesaan & Total \\
\hline Agustus 2020 & 8,90 & 4,55 & 6,91 \\
\hline Februari 2021 & 7,44 & 4,28 & 6,01 \\
\hline
\end{tabular}

Sumber: (BPS Sumatera Utara, 2021), diolah

Pandemi Covid-19 mulai terjadi di Sumatera Utara terhitung sejak Maret 2020 berdasarkan Surat Edaran Gubernur Sumatera Utara No. 440/2666/2020 tentang Peningkatan Kewaspadaan terhadap Resiko Penularan Infeksi COVID-19 di Sumatera Utara. Oleh karena itu, lonjakan tingkat pengangguran baik di wilayah perkotaan, wilayah perdesaan maupun secara total berdasarkan Tabel 1, tergambarkan mulai terjadi di Agustus 2020 dan mulai menurun di Februari 2021 namun persentasenya masih lebih tinggi dibandingkan Februari 2020. Pada Tabel 1 tersebut, lonjakan tingkat pengangguran paling tinggi terjadi di wilayah perkotaan hingaa kondisi Februari 2021. Meningkatnya tingkat pengangguran tersebut sebagai efek dari pembatasan aktivitas masyarakat sehingga banyak terjadi pemutusan hubungan kerja (PHK) kepada para karyawan, tutupnya berbagai aktivitas usaha karena tidak mampu memenuhi kebutuhan operasionalnya, dan sebagainya. Kondisi tersebut menunjukkan menurunnya tingkat produktivitas tenaga kerja secara umum di Sumatera Utara.

Permasalahan yang terjadi di Sumatera Utara tersebut juga turut mempengaruhi kondisi nasional maupun regional di pulau Sumatera. Oleh karena itu, penelitian ini mengurai masalah produktivitas Sumatera Utara melalui pendekatan disgaregasi produktivitas tenaga kerja secara sektoral serta identifikasi sebarannya dalam memetakan kekuatan ekonomi regionalnya sebagai salah satu upaya penguatan ekonomi regional di masa pandemi. Selain itu, identifikasi faktor yang memengaruhi produktivitas tenaga kerja dari berbagai dimensi seperti dimensi pendidikan, kesehatan, investasi, dan pendapatan juga menjadi hal yang perlu diperhatikan sebagai upaya menyusun perencanaan dan kebijakan dalam memperbaiki produktivitas khususnya di masa pandemi Covid-19.

\section{Landasan Teori}

ILO mengukur produktivitas tenaga kerja berdasarkan konsep total volume output (yang diukur dalam Produk Domestik Bruto, PDB) yang diproduksi per unit tenaga kerja (diukur dalam jumlah orang yang dipekerjakan) selama periode referensi waktu yang diberikan. Pertumbuhan ekonomi di suatu wilayah dapat menunjukkan pada seberapa efektif pekerjaan yang dilakukan oleh para pekerja, selain menunjukkan meningkatnya lapangan pekerjaan. Sehingga produktivitas tenaga kerja dapat dianggap sebagai salah satu ukuran utama kinerja ekonomi. Berbagai faktor pendorong khususnya akumulasi mesin dan peralatan, perbaikan organisasi serta infrastruktur fisik dan kelembagaan, peningkatan kesehatan dan keterampilan pekerja (modal manusia) dan generasi teknologi baru merupakan hal penting dalam merumuskan kebijakan untuk mendukung pertumbuhan ekonomi. Kebijakan tersebut dapat berfokus pada regulasi industri dan perdagangan, inovasi kelembagaan, program investasi pemerintah di infrastruktur serta 
sumber daya manusia, teknologi atau kombinasi dari semuanya. Perkiraan produktivitas tenaga kerja dapat mendukung perumusan kebijakan pasar tenaga kerja dan memantau efeknya. Misalnya, produktivitas tenaga kerja yang tinggi sering dikaitkan dengan tingkat atau jenis modal manusia tertentu yang menunjukkan prioritas untuk kebijakan pendidikan dan pelatihan tertentu. Demikian juga, tren dalam perkiraan produktivitas dapat digunakan untuk memahami efek dari penyelesaian upah pada tingkat inflasi atau untuk memastikan bahwa penyelesaian tersebut akan memberikan kompensasi kepada pekerja untuk peningkatan produktivitas (ILO, 2021).

Produktivitas tenaga kerja dipengaruhi oleh pendidikan, dan umur. Pendidikan menjadi pengetahuan bagi pekerja untuk mengerjakan tugasnya, dimana semakin baik pendidikannya maka semakin baik pula produktivitasnya. Umur erat kaitannya dengan kemampuan fisik dimana tenaga kerja dengan usia muda memiliki fisik yang prima dan mampu menghasilkan produktivitas yang besar. Semakin bertambahnya usia maka kemampuan fisik ikut menurun (Simanjuntak, 1985). Secara makro, komponen umur dapat diproksi dengan indikator Angka Harapan Hidup (AHH) yang dihitung oleh BPS. AHH adalah rata-rata tahun hidup yang masih akan dijalani seseorang yang telah berhasil mencapai umur $x$, pada suatu tahun tertentu, dalam situasi mortalitas yang berlaku di lingkungan masyarakatnya. Sementara itu, tingkat pendidikan secara makro dapat diproksi melalui indikator Rata-rata Lama Sekolah (RLS). RLS merupakan jumlah tahun yang digunakan oleh penduduk dalam menjalani pendidikan formal yang digunakan untuk mengetahui kualitas pedididikan masyarakat dalam suatu wilayah. Pemanfaatan AHH dan RLS dalam mengukur kualitas hidup manusia berdasarkan dimensi pendidikan dan kesehatan telah dilakukan oleh Raynaldhi (2016) dan Yektiningsih (2018).

Upah juga menjadi bagian penting dalam meningkatkan produktivitas tenaga kerja. Upah merupakan alasan dasar seseorang bekerja demi memenuhi kebutuhan hidup dan keluarganya serta meningkatkan status sosialnya. Selain itu, penentuan upah juga turut mempengaruhi keberlanjutan suatu usaha/ perusahaan. Sejalan dengan hal tersebut, Sukirno (2021) menyebutkan bahwa kenaikan tingkat upah akan meningkatkan produktivitas pekerja.

Modal fisik dalam ekonomi adalah hal mendasar yang menjadi sorotan utama karena dapat dilihat, disentuh dan digunakan secara langsung pada kegiatan usaha. Secara umum, modal fisik ini mencakup aset tetap dan aset lancar yang mengacu ke konsep Belkaoui (Syafri, 2012). Modal fisik yang diproksi dengan indikator PMTB menunjukkan pengaruh yang signifikan terhadap produktivitas tenaga kerja industri pengolahan besar dan sedang di Pulau Jawa (Sari \& Oktora, 2021). BAPPENAS (2020) merilis jenis infrastruktur ekonomi dalam indikator pembangunan ekonomi inklusif, diantaranya adalah Persentase Jalan dengan Kondisi Baik dan Sedang. Jalan merupakan salah satu komponen penyusunan indikator PMTB.

Pada penelitian sebelumnya, Sari \& Oktora (2021) dalam penelitiannya menemukan bahwa PMTB (modal fisik), IPM, dan upah riil menunjukkan pengaruh yang signifikan terhadap produktivitas tenaga kerja industri pengolahan besar dan sedang di Pulau Jawa dengan menggunakan metode regresi data panel. Fadillah et al., (2020) dalam 
penelitiannya menyimpulkan bahwa produktivitas tenaga kerja di Indonesia yang diukur dari perbandingan PDRB terhadap jumlah tenaga kerja dipengaruhi secara signifikan oleh infrastruktur ekonomi dan upah minimum provinsi, sedangkan variabel IPM tidak signifikan pengaruhnya. Oktavia et al., (2017) dalam penelitiannya mengenai analisis produktivitas tenaga kerja di Pulau Sumatera menemukan bahwa tingkat pendidikan yang diukur melalui jenjang pendidikan yang tertinggi yang ditamatkan memiliki pengaruh positif terhadap produktivitas tenaga kerja sektor pertanian. Selanjutnya, penelitian Wulandari (2018) menunjukkan bahwa produktivitas tenaga kerja industri besar dan sedang secara signifikan dipengaruhi oleh stok modal fisik (PMTB per tenaga kerja), stok modal manusia (proporsi tenaga kerja yang berpendidikan terakhir SMA ke atas), dan upah riil.

Bila dibandingkan dengan rangkuman penelitian tersebut, penelitian berfokus pada identifikasi produktivitas per lapangan usaha pertanian dan industri pengolahan, serta mengidentifikasi persebarannya. Selain itu, analisis inferensia dilakukan secara simultan dengan teknik multivariat untuk mengetahui pengaruh indikator makro terhadap produktivitas tenaga kerjanya secara sectoral. Periode penelitian ini membandingkan kondisi sebelum dan saat pandemi covid-19 baik secara deskriptif maupun inferensia.

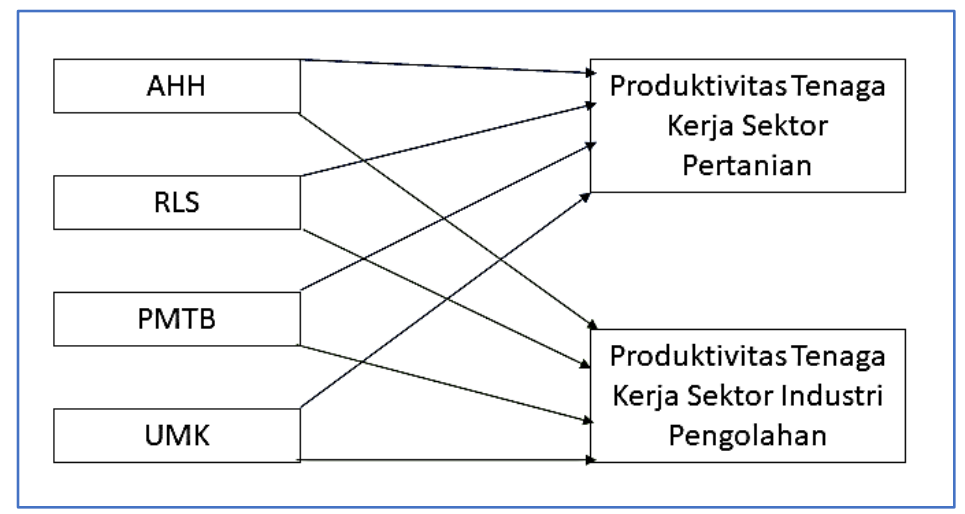

Gambar 1. Kerangka Konseptual

Berdasarkan hal tersebut diatas, rumusan hipotesis dalam penelitian ini adalah:

AHH, RLS PMTB dan UMK mempengaruhi produktivitas tenaga kerja di lapangan usaha pertanian dan industri pengolahan di Sumatera Utara.

\section{Metode}

\subsection{Jenis dan Sumber Data}

Penelitian ini menggunakan data sekunder tahun 2019 dan 2020 menurut kabupaten/kota di Sumatera Utara yang diperoleh dari website BPS Provinsi Sumatera Utara, berupa data Produk Domestik Regional Bruto (PDRB) Atas Dasar Harga Konstan 2010 (ADHK $2010=100$ ) menurut lapangan usaha pertanian dan industri pengolahan, jumlah tenaga kerja menurut lapangan usaha, Rata-rata Lama Sekolah (RLS), Angka Harapan Hidup (AHH), Pembentukan Modal Tetap Bruto (PMTB), dan Upah Minimum Kabupaten/ Kota (UMK). Selain itu, tulisan ini menggunakan file format shp Sumatera Utara menurut kabupaten/kota untuk penyusunan peta tematik. 
Analisis data menggunakan metode regresi multivariat yang disajikan dalam bentuk matriks sebagai berikut.

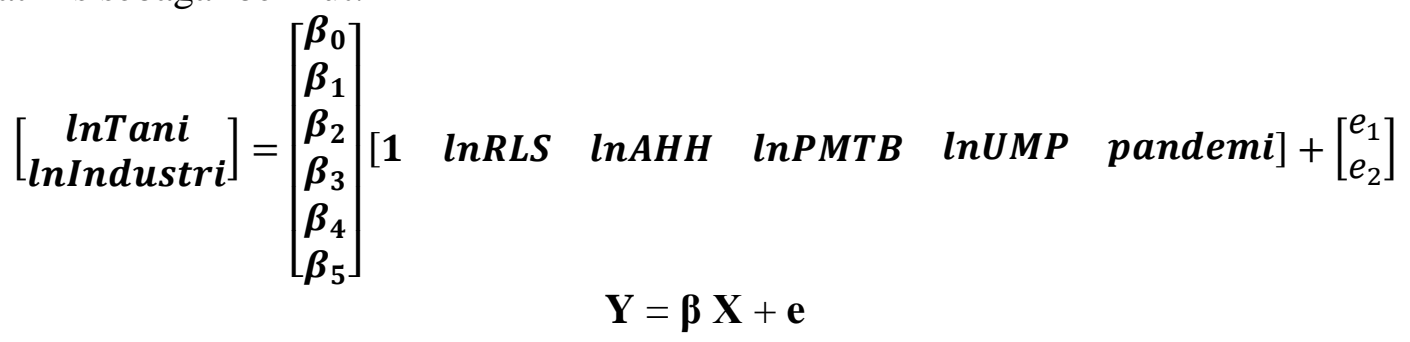

Penaksiran parameter model regresi menggunakan metode Weighted Least Square (WLS) dengan menggunakan penimbang invers variabel produktivitas tenaga kerja di lapangan usaha industri pengolahan. Metode WLS memiliki kemampuan menetralisasi akibat pelanggaran asumsi heteroskedastisitas dan dapat mengatasi ketidakbiasan dan konsistensi dari model taksiran Least Square (Montgomery et al., 2012).

\section{Hasil analisis dan Pembahasan}

Pada bagian ini akan disajikan informasi yang berisi hasil analisis dan pembahasan diantaranya gambaran produktivitas tenaga kerja, deskripsi variabel makro,uji kualitas data, pemodelan, evaluasi model, determinan produktivitas tenaga kerja.

\subsection{Gambaran Produktivitas Tenaga Kerja Pertanian di Sumatera Utara}

Berikut informasi gambaran produktivitas tenaga kerja pertanian yang terdapat di Sumatera Utara.

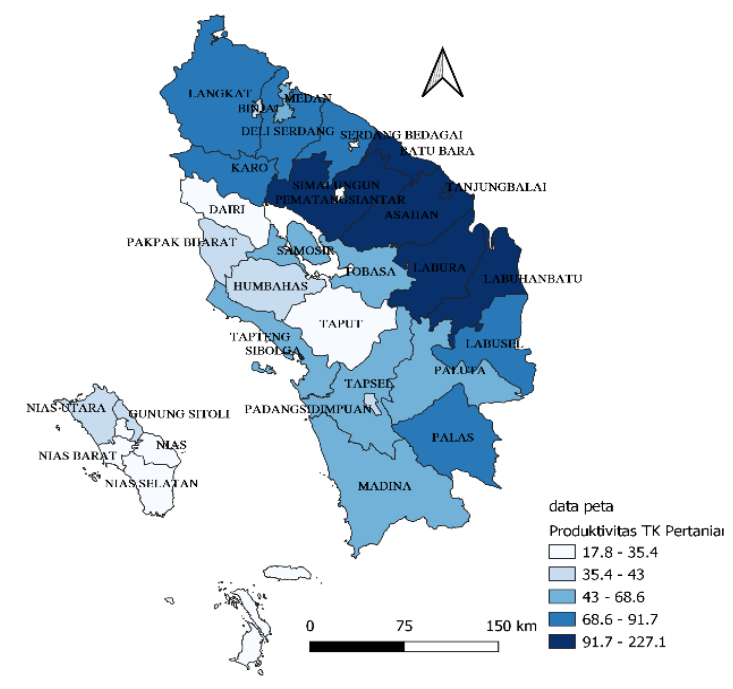

(a) Tahun 2019

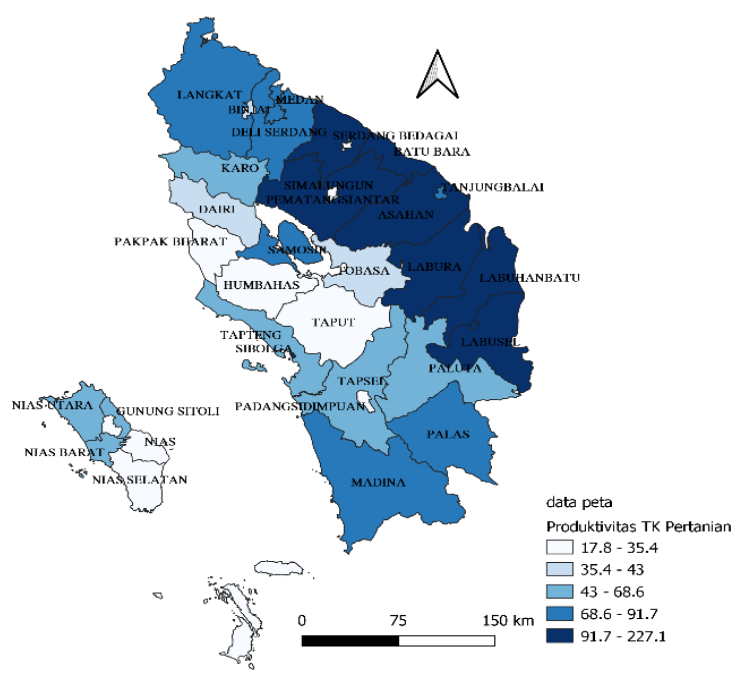

(b) Tahun 2020

Gambar 2. Peta Tematik Produktivitas Tenaga Kerja di Pertanian di Sumatera Utara

Secara umum, produktivitas tenaga kerja lapangan usaha pertanian di Sumatera Utara menurun di masa pandemi, yaitu dari 56,32 juta rupiah per kapita pada tahun 2019 menjadi 56,24 juta rupiah per kapita pada tahun 2020 (kondisi pandemi). Kondisi ini terjadi karena besarnya pertumbuhan nilai tambah bruto pertanian tidak sebesar pertumbuhan jumlah tenaga kerjanya. Keadaan tersebut ditambah lagi dengan struktur 
pekerja informal yang meningkat di masa pandemi, menurut Badan Pusat Statistik (2020) tenaga kerja informal pada Agustus 2020 meningkat sekitar 5,34 persen sedangkan pekerja formal menurun sekitar 9,62 persen dibandingkan kondisi Agustus 2019. Keberadaan tenaga kerja informal di bidang pertanian yang umumnya banyak bergerak pada skala usaha kecil/ usaha keluarga, serta cenderung memiliki tingkat upah dan produktivitas yang rendah, belum mampu menggenjot produktivitas tenaga kerja di lapangan usaha pertanian meskipun banyak yang beralih ke sektor pertanian selama masa pandemi.

Bila dilihat sebarannya pada peta tematik di Gambar 2, terjadi penurunan maupun peningkatan produktivitas tenaga kerja pertanian pada level kabupaten/kota. Penurunan produktivitas tenaga kerja pertanian yang cukup tinggi terjadi di wilayah Dataran Tinggi (Humbang Hasundutan, Pakpak Bharat, Toba Samosir, dan Karo). Sementara itu, peningkatan produktivitas tenaga kerja pertanian yang cukup tinggi terjadi di hampir semua wilayah, seperti di Wilayah Pantai Timur (Medan, Serdang Bedagai, Labuhan Batu Selatan), Wilayah Pantai Selatan (Madina), Wilayah Dataran Tinggi (Samosir, Dairi), dan Wilayah Kepulauan Nias (Nias Utara, Nias Barat, Gunung Sitoli). Meskipun peningkatan produktivitas tersebut terjadi hampir di setiap wilayah tetapi belum memberikan kontribusi besar bagi produktivitas tenaga kerja pertanian secara umum.

Produktivitas tenaga kerja pertanian tertinggi pada tahun 2019 maupun 2020 berada di Kota Sibolga, meskipun kondisi tahun 2020 lebih rendah yaitu dari 227,14 juta rupiah per tenaga kerja per tahun menjadi 201,47 juta rupiah per tenaga kerja per tahun. Kota Sibolga merupakan sumber potensi perikanan Sumatera Utara yang berada di Wilayah Pantai Barat. Meskipun produktivitasnya tinggi namun kontribusi pertanian Sibolga terhadap Sumatera Utara cukup rendah yaitu sekitar 0,56 persen pada tahun 2020, sehingga produktivitasnya belum memberikan peran terhadap produktivitas tenaga kerja pertanian Sumatera Utara. Sementara itu, pertanian Sumatera Utara yang cukup besar ditopang olah Simalungun dan Deli Serdang masing-masing kontribusi sekitar 11,33 persen dan 6,62 persen namun produktivitas tenaga kerja pertaniannya menurun selama masa pandemi dan sangat berefek pada produktivitas tenaga kerja pertanian Sumatera Utara.

Pertanian di Wilayah Pantai Timur Provinsi Sumatera Utara memiliki potensi perkebunan khususnya komoditas kelapa sawit dimana sekitar 44,44 persen areal perkebunan kelapa sawit Sumatera Utara berada di kawasan ini (BPS Provinsi Sumatera Utara, 2021). Seperti di Kabupaten Labuhan Batu dan sekitarnya yang perekonomiannya disokong oleh kegiatan perkebunan kelapa sawit. Selain itu terdapat perusahaan kelapa sawit berskala nasional di kawasan tersebut dengan volume output yang besar dan berpengaruh pada besarnya nilai produktivitas tenaga kerjanya. Hal tersebut sejalan dengan analisis matriks neraca social yang dilakukan oleh Siregar (2018) bahwa aktivitas perkebunan di Sumatera Utara memberikan efek pengganda terutama dalam penciptaan lapangan pekerjaan.

Produktivitas tenaga kerja sektor pertanian paling rendah berada di Padangsidimpuan, Medan, Binjai, Gunungsitoli, Pematangsiantar, dan Tebingtinggi yang 
merupakan area perkotaan. Area tersebut memiliki lahan pertanian yang semakin sempit sehingga lapangan pekerjaan lebih berkembang ke sektor industri maupun jasa.

\subsection{Gambaran Produktivitas Tenaga Kerja Industri Pengolahan di Sumatera Utara}

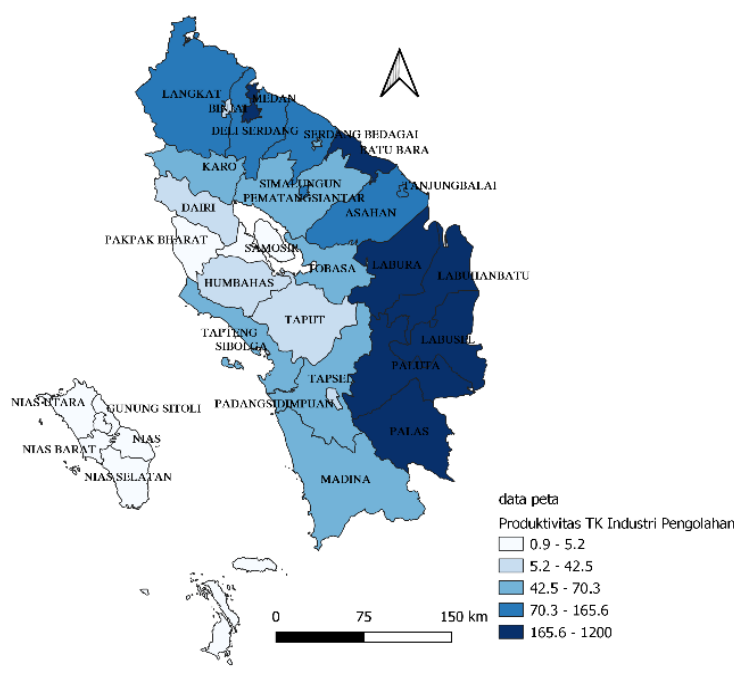

(a) Tahun 2019

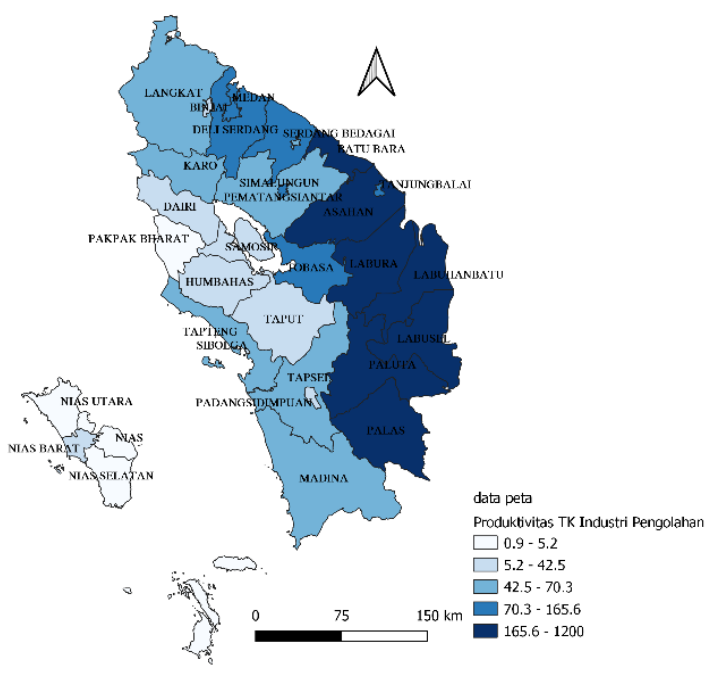

(b) Tahun 2020

Gambar 3. Peta Tematik Produktivitas Tenaga Kerja di Industri Pengolahan di Sumatera Utara

Secara umum, produktivitas tenaga kerja lapangan usaha industri pengolahan di Sumatera Utara menurun di masa pandemi, yaitu dari 87,30 juta rupiah per kapita pada tahun 2019 menjadi 86,32 juta rupiah per kapita pada tahun 2020 (kondisi pandemi). Kondisi ini juga terjadi karena nilai tambah bruto industri pengolahan terkontraksi sedangkan jumlah tenaga kerjanya bertambah. Bila dilihat dari struktur tenaga kerjanya, menurut Badan Pusat Statistik (2020) tenaga kerja informal di industri pengolahan pada Agustus 2020 meningkat sekitar 17,54 persen sedangkan pekerja formal menurun sekitar 9,78 persen dibandingkan kondisi Agustus 2019. Keberadaan tenaga kerja informal di bidang industri umumnya banyak bergerak pada usaha sendiri dengan skala usaha kecil/ usaha keluarga, dan para pekerja bebas cenderung memiliki tingkat upah dan produktivitas yang rendah sehingga belum mampu menggenjot produktivitas tenaga kerja di lapangan usaha industri pengolahan meskipun kegiatan UKM merupakan tumpuan masyarakat untuk bertahan selama pandemi.

Bila dilihat sebarannya pada peta tematik di Gambar 3, juga terlihat pola produktivitas tenaga kerja industri pengolahan yang naik naik maupun turun sebelum dan saat pandemi. Penurunan produktivitas tenaga kerja pertanian cukup terlihat terjadi di wilayah Pantai Timur (Langkat dan Medan). Sementara itu, peningkatan produktivitas tenaga kerja juga cukup terlihat Wilayah Pantai Timur (Asahan). Penurunan produktivitas tenaga kerja industri pengolahan di Medan sangat mempengaruhi kondisi Sumatera Utara karena kontribusi Medan terhadap industri pengolahan Sumatera Utara sekitar 21,42 persen. 
Produktivitas tenaga industri pengolahan tertinggi pada tahun 2019 maupun 2020 berada di Labuhan Batu Selatan, dan kondisi tersebut meningkat dari 1,13 milyar rupiah per tenaga kerja per tahun pada 2019 menjadi 1,14 milyar rupiah per tenaga kerja per tahun pada 2020. Labuhan Batu Selatan merupakan sumber potensi perkebunan kelapa sawit dan industri pengolahan kelapa sawit Sumatera Utara yang berada di Wilayah Pantai Timur. Pertanian dan Industri pengolahan merupakan sektor basis di kabupaten tersebut berdasarkan analisis LQ (BPS Sumatera Utara, 2021). Kontribusi industri pengolahan Labuhan Batu Selatan terhadap Sumatera Utara sekitar 7,77 persen pada tahun 2020 (BPS Sumatera Utara, 2021), namun masih lebih rendah dari kontribusi Medan yang mencapai 21,42 persen. Sehingga produktivitasnya belum memberikan peran terhadap produktivitas tenaga kerja pertanian Sumatera Utara karena produktivitas tenaga kerja di Medan menurun efek pandemi Covid-19.

Produktivitas tenaga kerja sektor pertanian paling rendah berada di Gunung Sitoli, Nias Selatan, Pakpak Bharat, dan Nias Utara dimana berdasarkan analisis LQ yang dilakukan BPS Provinsi Sumatera Utara (2020) bahwa daerah tersebut bukan basis industri pengolahan.

\subsection{Deskripsi Variabel Makro}

Deskripsi data makro pada penelitian ini disajikan secara visual pada Gambar 4. Variabel PMTB, produktivitas tenaga kerja di pertanian maupun industri pengolahan di level provinsi mengalami penurunan pada tahun 2019 ke 2020. Sementara itu, variabel lainnya seperti AHH, RLS maupun UMP di level provinsi menunjukkan peningkatan. Bila dicermati kembali pada level kabupaten/ kota, PMTB tertinggi berada di Medan dan mengalami penurunan pada 2020 efek covid-19. Produktivitas tenaga kerja pertanian tertinggi pada tahun 2019 hingga 2020 terjadi di Sibolga meskipun mengalami penurunan pada tahun 2020. Produktivitas tenaga kerja pertanian di Sibolga lebih tinggi dari Provinsi Sumatera Utara. Sementara itu, produktivitas tenaga kerja industri pengolahan tertinggi berada di Labuhan Batu Selatan dan mengalami pada tahun 2020. Bila dibandingkan dengan produktivitas provinsi, Labuhan Batu Selatan masih lebih tinggi.

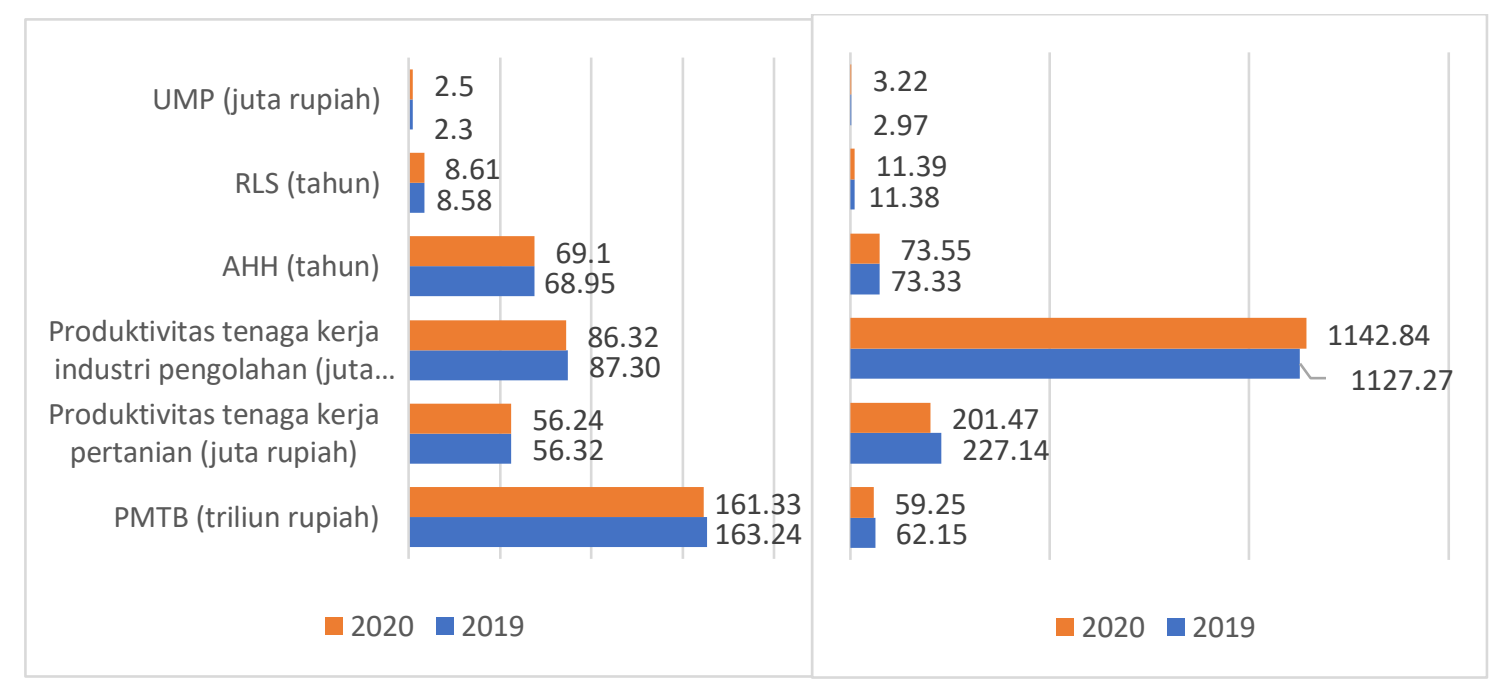

Gambar 4. Deskripsi Data Makro di Sumatera Utara 
AHH paling tinggi berada di Pematangsiantar untuk tahun 2019 hingga 2020, dan angka tersebut lebih tinggi daripada level provinsi. Hal ini menunjukkan bahwa pembangunan di dimensi kesehatan di Pematangsiantar sduah lebih baik dari kabupaten/kota lainnya. Sementara itu, pembangunan dimensi pendidikan yang digambarkan oleh variabel RLS, menunjukkan bahwa Medan memiliki pembangunan pendidikan yang lebih baik dari kabupaten/kota lainnya bahkan dari level provinsi. Tingkat upah di Medan juga paling tinggi diantara kabupaten/kota lainnya bahkan lebih tinggi dari UMP.

\subsection{Pengujian Kualitas Data}

Pengujian kualitas data dilakukan untuk mengetahui apakah data yang digunakan bisa dianalisis secara multivariat atau tidak, yaitu melalui uji asumsi dependensi multivariat dan multivariat normal.

\subsubsection{Asumsi Dependensi Multivariat}

Pengujian asumsi dependensi dilakukan untuk mengetahui apakah antar variabel respon berkorelasi secara multivariat atau tidak.

$\mathrm{H}_{0}$ : Variabel respon bersifat independen

$\mathrm{H}_{1}$ : Variabel respon bersifat dependen

Tabel 2

Hasil Uji Dependensi Multivariat

\begin{tabular}{ccl}
\hline$\chi^{2}$ & $\chi^{2}(0,05 ; 1)$ & Keputusan \\
\hline 24,312 & 3,841 & $\mathrm{H}_{0}$ ditolak \\
\hline
\end{tabular}

Tabel 2 menunjukkan bahwa nilai $\chi^{2}$ hitung lebih dari $\chi^{2}$ tabel dengan taraf signifikansi sebesar 5\%, sehingga diperoleh keputusan menolak $\mathrm{H}_{0}$. Hal ini berarti bahwa variabel respon yang digunakan dalam penelitian ini saling berkorelasi atau dependen secara multivariat.

\subsubsection{Asumsi Normal Multivariat}

Hipotesis pada uji asumsi normal multivariat adalah sebagai berikut.

$\mathrm{H}_{0}$ : Variabel respon tidak berdistribusi normal multivariat

$\mathrm{H}_{1}$ : Variabel respon berdistribusi normal multivariat

Tabel 3

Hasil Uji Normal Multivariat

\begin{tabular}{cc}
\hline Kriteria & Proporsi \\
\hline $\mathrm{di}^{2}$ & 0,545 \\
\hline
\end{tabular}

Dari Tabel 3 diketahui bahwa nilai jarak mahalanobis yang kurang dari nilai $\chi^{2}$ tabel memiliki proporsi 0,545 atau $54,5 \%$. Hal ini berarti nilai $\mathrm{di}^{2}>50 \%$ sehingga dapat disimpulkan bahwa variabel respon berdistribusi normal multivariat. Pada hasil pengujian kualitas data, diketahui bahwa variabel respon bersifat dependen secara multivariat dan berdistribusi normal multivariat. Hal ini telah memenuhi asumsi data untuk analisis regresi multivariat. 


\subsection{Pemodelan}

Pemodelan dilakukan dengan metode regresi multivariat antara variabel prediktor yaitu RLS, AHH, PMTB, UMP, dan dummy pandemi terhadap variabel respon yang terdiri produktivitas tenaga kerja di lapangan usaha pertanian dan lapangan usaha industri pengolahan.

\subsubsection{Uji Serentak}

Pengujian secara serentak dilakukan untuk mengetahui apakah ada variabel prediktor yang berpengaruh signifikan secara simultan terhadap variabel respon. Hipotesis pada yang digunakan yaitu:

$\mathrm{H}_{0}: \beta_{j k}=0 ; j=1,2,3$ dan $k=1,2,3,4,5$ (tidak ada variabel prediktor yang berpengaruh signifikan terhadap variabel respon)

$\mathrm{H}_{1}$ : minimal ada satu $\beta_{j k} \neq 0$ (minimal ada satu variabel prediktor yang signifikan terhadap variabel respon)

\section{Tabel 4}

Hasil Pengujian Serentak

\begin{tabular}{cccc}
\hline Statistik Uji & $\wedge$ & $\wedge_{0,05 ; 4 ; 2 ; 63}$ & Keputusan \\
\hline $\begin{array}{c}\text { Wilk's } \\
\text { Lambda }\end{array}$ & 0,244 & 0,78165 & $\mathrm{H}_{0}$ ditolak \\
\hline
\end{tabular}

Tabel 4 menunjukkan bahwa nilai Wilk's Lambda hitung lebih kecil dari nilai critical point Wilk's Lambda, sehingga diperoleh keputusan $\mathrm{H}_{0}$ ditolak. Hal ini berarti terdapat minimal satu variabel prediktor yang signifikan terhadap variabel respon

\subsubsection{Uji Parsial}

Pengujian secara parsial dilakukan untuk mengetahui apakah masing-masing variabel prediktor berpengaruh signifikan terhadap variabel respon. Hipotesis pengujiannya adalah:

$\mathrm{H}_{0}: \beta_{j k}=0$ (variabel prediktor ke-j tidak berpengaruh signifikan terhadap variabel respon ke- $k)$

$\mathrm{H}_{1}: \quad \beta_{j k} \neq 0$ (variabel prediktor ke-j berpengaruh signifikan terhadap variabel respon ke$k)$

\section{Tabel 5}

Hasil Pengujian Parsial

\begin{tabular}{cccc}
\hline Variabel & $\wedge$ & P-value & Keputusan \\
\hline LnRLS & 0,582 & 0,000 & $\mathrm{H}_{0}$ ditolak \\
LnAHH & 0,954 & 0,262 & $\mathrm{H}_{0}$ gagal ditolak \\
LnPMTB & 0,789 & 0,001 & $\mathrm{H}_{0}$ ditolak \\
LnUMP & 0,552 & 0,000 & $\mathrm{H}_{0}$ ditolak \\
Dummy & 0,817 & 0,003 & $\mathrm{H}_{0}$ ditolak \\
Pandemi & & & \\
\hline
\end{tabular}

Dari Tabel 5 diketahui bahwa semua variabel bebas signifikan pada taraf signifikansi 5\% mempengaruhi produktivitas tenaga kerja di pertanian dan industri pengolahan. Selanjutnya identifikasi besarnya hubungan antara variabel respon dengan 
variabel prediktor yang signifikan dengan menggunakan eta square lambda $\left(\eta_{\Lambda}^{2}\right)$. Hasil perhitungan eta square lambda adalah sebagai berikut.

$\eta_{\Lambda}^{2}=1-\Lambda$

$\eta_{\Lambda}^{2}=1-0,244=0,756$

Berdasarkan perhitungan di atas diperoleh nilai eta square lambda sebesar 0,756. Hal ini menunjukkan bahwa variabilitas model respon dapat dijelaskan oleh variabel RLS, SHH, PMTB, UMP, dan dummy pandemi sebesar 75,6 persen, sedangkan sisanya sebesar 24,4 persen dijelaskan oleh variabel prediktor lain di luar.

\subsection{Evaluasi Model}

Asumsi-asumsi yang harus terpenuhi untuk memperoleh model terbaik sebagai berikut.

\subsubsection{Asumsi Residual Independen}

Metode yang digunakan yaitu uji Bartlett Spericity. Hasil analisisnya adalah sebagai berikut.

$\mathrm{H}_{0}$ : Residual saling bebas (independen)

$\mathrm{H}_{1}$ : Residual tidak saling bebas (dependen)

Tabel 6. Asumsi Residual Independen

\begin{tabular}{ccc}
\hline$\chi^{2}$ & $\chi^{2}(0,05 ; 10)$ & Keputusan \\
\hline 4,86 & 18,307 & Ho $_{0}$ gagal ditolak \\
\hline
\end{tabular}

Tabel 6 menunjukkan bahwa nilai chi-square hitung lebih kecil dari chi-square tabel pada taraf signifikan 0,05. Dari hasil tersebut maka dapat disimpulkan bahwa residual data saling bebas yang artinya telah memenuhi asumsi dependen

\subsubsection{Asumsi Residual Normal Multivariat}

Metode yang digunakan adalah proporsi jarak mahalanobis yang kurang dari nilai $\chi^{2}$ tabel lebih dari $50 \%$.

$\mathrm{H}_{0}$ : Residual tidak berdistribusi normal multivariat

$\mathrm{H}_{1}$ : Residual berdistribusi normal multivariat

Tabel 7. Asumsi Residual Normal Multivariat

\begin{tabular}{cc}
\hline Kriteria & Proporsi \\
\hline $\mathrm{di}^{2}$ & 0,5781
\end{tabular}

Dari Tabel 7 diketahui bahwa nilai jarak mahalanobis yang kurang dari nilai $\chi^{2}$ tabel memiliki proporsi 0,5781 atau $57,81 \%$. Hal ini berarti nilai $\mathrm{di}^{2}>50 \%$ sehingga dapat disimpulkan bahwa residual data berdistribusi normal multivariat. Berdasarkan evaluasi yang telah dilakukan, diketahui bahwa model telah memenuhi asumsi independen, dan berdistribusi normal multivariat sehingga model yang terbentuk sudah layak digunakan.

\subsection{Determinan Produktivitas Tenaga Kerja Sektor Pertanian dan Sektor Industri}

Berdasarkan hasil analisis diperoleh informasi tentang determinan produktivitas tenaga kerja pada sektor pertanian dan sektor industri (tabel 8). 


\section{Tabel 8}

Hasil Estimasi Parameter Model Regresi Multivariat dengan Metode WLS

\begin{tabular}{|c|c|c|c|c|c|c|c|}
\hline $\begin{array}{c}\text { Variabel } \\
\text { Dependen }\end{array}$ & Parameter & B & P-Value & $\begin{array}{c}\text { Variabel } \\
\text { Dependen }\end{array}$ & Parameter & B & $\begin{array}{c}P- \\
\text { Value } \\
\end{array}$ \\
\hline \multirow{6}{*}{ LnTani } & Intersep & $-24,552$ & $0,004 *$ & \multirow{6}{*}{ LnIndustri } & Intersep & $-84,816$ & $0,001^{*}$ \\
\hline & LnRLS & 0,404 & $0,019 *$ & & LnRLS & 3,134 & $0,000^{*}$ \\
\hline & LnAHH & $-2,341$ & 0,103 & & LnAHH & $-2,727$ & 0,512 \\
\hline & LnPMTB & $-0,032$ & 0,562 & & LnPMTB & 0,579 & $0,001 *$ \\
\hline & LnUMP & 4,850 & $0,000 *$ & & LnUMP & 10,760 & $0,000^{*}$ \\
\hline & $\begin{array}{l}\text { Dummy } \\
\text { Pandemi }\end{array}$ & $-0,220$ & $0,009 *$ & & $\begin{array}{l}\text { Dummy } \\
\text { Pandemi }\end{array}$ & $-0,730$ & $0,003 *$ \\
\hline
\end{tabular}

Keterangan: *) signifikan pada tingkat signifikansi 5\%

\subsection{Pembahasan}

Berdasarkan Tabel 8 diketahui bahwa variabel yang signifikan mempengaruhi produktivitas tenaga kerja pertanian di Sumatera Utara dengan tingkat signifikansi 5 persen adalah RLS, AHH, UMP, dan dummy konisi pandemi covid-19. Sementara itu, variabel AHH dan PMTB tidak signifikan mempengaruhi produktivitas tenaga kerja pertanian. Nilai koefisien regresi RLS adalah sebesar 0,404 dan bernilai positif, hal ini berarti bahwa RLS berpengaruh positif terhadap produktivitas tenaga kerja pertanian di Sumatera Utara. Hal ini dapat diinterpretasikan bahwa setiap pertumbuhan 1 persen dimensi pendidikan yang tercermin dari RLS akan mempengaruhi meningkatnya produktivitas tenaga kerja pertanian di Sumatera Utara sebesar 0,404 persen dengan asumsi variabel lainnya konstan. Hal ini sejalan dengan penelitian Wulandari (2018) dan Oktavia et al. (2017) yang menyimpulkan bahwa pendidikan berpengaruh terhadap peningkatan produktivitas tenaga kerja pertanian. Teori yang dikemukakan Simanjuntak (1985) juga menyebutkan bahwa produktivitas tenaga kerja dipengaruhi oleh pendidikan karena pendidikan menjadi pengetahuan bagi pekerja untuk mengerjakan tugasnya, dimana semakin baik pendidikannya maka semakin baik pula produktivitasnya.

Nilai koefisien regresi UMP adalah sebesar 4,850 dan bernilai positif, hal ini berarti bahwa UMP berpengaruh positif terhadap produktivitas tenaga kerja pertanian di Sumatera Utara. Hal ini dapat diinterpretasikan bahwa setiap pertumbuhan 1 persen tingkat upah akan mempengaruhi meningkatnya produktivitas tenaga kerja pertanian di Sumatera Utara sebesar 4,85 persen dengan asumsi variabel lainnya konstan. Hal ini sejalan dengan penelitian Sari \& Oktora (2021), Fadillah et al. (2020), dan Wulandari (2018) yang juga menyimpulkan bahwa tingkat upah berpengaruh positif terhadap peningkatan produktivitas tenaga kerja. Sukirno (2012: 353) juga menyebutkan bahwa kenaikan tingkat upah akan meningkatkan produktivitas pekerja. Kondisi tersebut sejalan dengan komposisi tenaga kerja sektor pertanian di Sumatera Utara terdiri dari 29,95 persen pekerja bebas dan buruh/ karyawan (Badan Pusat Statistik, 2020). Jumlah buruh/ karyawan maupun pekerja bebas yang cukup besar tersebut sangat mempengaruhi produktivitas di sektor pertanian. Semakin besar upah yang ditawarkan akan semakin baik pula kinerja para buruh/karyawan dan pekerja lepas tersebut. Hal tersebut sejalan dengan penelitian Sumarlin \& Sirojuzilam (2010) yang menyebutkan teori upah efisiensi Cafferty 
(1990) bahwa produktivitas pekerja dipengaruhi oleh tingkat upah. Upah yang tinggi dapat memenuhi kebutuhan hidup dengan pola makanan yang bergizi sehingga tubuh menjadi sehat, dan alokasi waktu kerjanya menjadi lebih baik dan pada akhirnya produktivitas kerja meningkat.

Nilai koefisien regresi dummy pandemi covid-19 adalah sebesar $-0,220$ dan bernilai negatif, hal ini berarti bahwa kondisi pandemi covi-19 berpengaruh negatif terhadap produktivitas tenaga kerja pertanian di Sumatera Utara. Hal ini dapat diinterpretasikan bahwa kondisi pandemi akan menurunkan pertumbuhan produktivitas tenaga kerja pertanian di Sumatera Utara sebesar 0,22 persen dengan asumsi variabel lainnya konstan. Hasil tersebut sejalan dengan deskripsi variabel produktivitas tenaga kerja sektor pertanian yang menurun di kala pandemik baik di level provinsi maupun di beberapa kabupaten/kota.

Berdasarkan Tabel 8 diketahui bahwa variabel yang signifikan mempengaruhi produktivitas tenaga kerja industri pengolahan di Sumatera Utara dengan tingkat signifikansi 5 persen adalah RLS, PMTB, AHH, UMP, dan dummy konisi pandemi covid19. Sementara itu, variabel AHH tidak signifikan mempengaruhi produktivitas tenaga kerja industri pengolahan. Nilai koefisien regresi RLS adalah sebesar 3,134 dan bernilai positif, hal ini berarti bahwa RLS berpengaruh positif terhadap produktivitas tenaga kerja industri pengolahan di Sumatera Utara. Hal ini dapat diinterpretasikan bahwa setiap pertumbuhan 1 persen dimensi pendidikan yang tercermin dari RLS akan mempengaruhi meningkatnya produktivitas tenaga kerja industri pengolahan di Sumatera Utara sebesar 3,134 persen dengan asumsi variabel lainnya konstan. Hal ini sejalan dengan penelitian Sari \& Oktora (2021) dan Fadillah et al. (2020), yang menyimpulkan bahwa produktivitas tenaga kerja sektor industri di Kota Semarang dipengaruhi oleh tingkat pendidikan. Hal tersebut searah dengan Simanjuntak (1985) yang menyebutkan produktivitas tenaga kerja dipengaruhi oleh dimana semakin baik pendidikannya maka semakin baik pula produktivitasnya. Apalagi kasus di industri pengolahan membutuhkan tenaga kerja yang terlatih untuk menyelesaikan target produksi.

Nilai koefisien regresi PMTB adalah sebesar 0,579 dan bernilai positif, hal ini berarti bahwa PMTB berpengaruh positif terhadap produktivitas tenaga kerja industri pengolahan di Sumatera Utara. Hal ini dapat diinterpretasikan bahwa setiap pertumbuhan 1 persen tingkat upah akan mempengaruhi meningkatnya produktivitas tenaga kerja industri pengolahan di Sumatera Utara sebesar 0,579 persen dengan asumsi variabel lainnya konstan. Hal ini sejalan dengan penelitian Sari \& Oktora (2021) yang menunjukkan bahwa PMTB berupa jalan berpengaruh positif terhadap produktivitas tenaga kerja sektor industri. PMTB merupakan salah bentuk modal fisik berupa investasi baik dalam bentuk bangunan maupun non bangunan yang dapat menyokong aktivitas ekonomi. Penelitian Fadillah et al. (2020) juga menunjukkan bahwa infrastruktur ekonomi signifikan mempengaruh produktivitas tenaga kerja. Belkaoui dalam Syafri (2012) menyebutkan bahwa modal fisik mencakup aset tetap dan aset lancar.

Nilai koefisien regresi UMP adalah sebesar 10,760 dan bernilai positif, hal ini berarti bahwa UMP berpengaruh positif terhadap produktivitas tenaga kerja industri 
pengolahan di Sumatera Utara. Hal ini dapat diinterpretasikan bahwa setiap pertumbuhan 1 persen tingkat upah akan mempengaruhi meningkatnya produktivitas tenaga kerja industri pengolahan di Sumatera Utara sebesar 10,760 persen dengan asumsi variabel lainnya konstan. Hal ini sejalan dengan penelitian Sari \& Oktora (2021), Fadillah et al. (2020), dan Wulandari (2018) juga menyimpulkan bahwa tingkat upah berpengaruh positif terhadap peningkatan produktivitas tenaga kerja sektor industri. Sukirno (2012: 353) juga menyebutkan bahwa kenaikan tingkat upah akan meningkatkan produktivitas pekerja. Sektor industri memiliki komposisi tenaga kerja yang didominasi buruh/ karyawan serta pekerja bebas atau sekitar 68,50 persen menurut rilis BPS Sumatera Utara tahun 2019. Komposisi buruh/karyawan serta pekerja bebas yang sangat besar tersebut sangat erta kaitannya dengan tingkat upah yang diperoleh. Hasil tersebut juga sejalan dengan teori Cafferty dalam penelitian (Sumarlin \& Sirojuzilam, 2010).

Nilai koefisien regresi dummy pandemi covid-19 adalah sebesar -0,730 dan bernilai negatif, hal ini berarti bahwa kondisi pandemi covi-19 berpengaruh negatif terhadap produktivitas tenaga kerja industri pengolahan di Sumatera Utara. Hal ini dapat diinterpretasikan bahwa kondisi pandemi akan menurunkan pertumbuhan produktivitas tenaga kerja industri pengolahan di Sumatera Utara sebesar 0,73 persen dengan asumsi variabel lainnya konstan. Hasil tersebut sejalan dengan deskripsi variabel produktivitas tenaga kerja industri pengolahan yang menurun di kala pandemik baik di level provinsi maupun di beberapa kabupaten/kota. Dampak pandemi lebih besar terhadap prouktivitas tenaga kerja industri pengolahan daripada pertanian berdaasrkan koefisen regresinya.

\section{Simpulan}

Berdasarkan hasil analisis dan pembahasan, penelitian ini dapat disimpulkan beberapa poin penting. Pertama, produktivitas tenaga kerja pertanian di Sumatera Utara menurun di masa pandemi (tahun 2020). Penurunan tersebut juga dipicu oleh penurunan produktivitas tenaga kerja pada kabupaten yang memiliki kontribusi pertanian yang tinggi terhadap Sumatera Utara, seperti Kabupaten Deli Serdang dan Kabupaten Simalungun. Sementara itu, Kota Sibolga memiliki kontribusi produktivitas pertanian tertinggi di Sumatera Utara baik sebelum dan di masa pandemi yang didorong oleh kegiatan perikanan, namun produktivitas tersebut belum menunjukkan peran yang besar terhadap Sumatera Utara karena kontribusi pertanian Kota Sibolga tergolong kecil. Kedua, produktivitas tenaga kerja industri pengolahan di Sumatera Utara menurun di masa pandemi (tahun 2020). Penurunan tersebut juga dipicu oleh penurunan produktivitas tenaga kerja pada kabupaten/kota yang memiliki kontribusi industri pengolahan yang tinggi terhadap Sumatera Utara, seperti Kota Medan. Sementara itu, Kabupaten Labuhan Batu Selatan memiliki kontribusi produktivitas industri pengolahan tertinggi di Sumatera Utara baik sebelum dan di masa pandemi. Peran industri pengolahan Labuhan Batu Selatan berada di posisi ke-4 sehingga besarnya produktivitas tersebut belum menunjukkan peran yang besar terhadap Sumatera Utara karena Kota Medan yang memiliki kontribusi terbesar di Sumatera Utara mengalami kontraksi produktivitas tenaga kerja industri pengolahan. 
Ketiga, indikator makro berupa RLS, AHH, dan UMP menunjukkan peningkatan di masa pandemi, namun PMTB menunjukkan tren yang menurun. Keempat, RLS, dan UMP berpengaruh positif terhadap tingkat produktivitas tenaga kerja pertanian di Sumatera Utara, sedangkan kondisi pandemi berpengaruh negatif. Sementara itu, PMTB dan AHH tidak signifikan pengaruhnya terhadap tingkat produktivitas tenaga kerja pertanian di Sumatera Utara. Kelima, RLS, PMTB dan UMP berpengaruh positif terhadap tingkat produktivitas tenaga kerja industri pengolahan di Sumatera Utara, sedangkan kondisi pandemi berpengaruh negatif. Sementara itu, AHH tidak signifikan pengaruhnya terhadap tingkat produktivitas tenaga kerja industri pengolahan di Sumatera Utara.

\subsection{Implikasi Teoritis}

Penelitian ini diharapkan mampu menambah wawasan mengenai teori yang berhubungan dengan produktivitas tenaga kerja khususnya di kondisi pandemic Covid-19 yang telah banyak mengubah tatanan kehidupan termasuk aktivitas ekonomi baik di sektor pertanian maupun industri pengolahan. Penggunaan teori tersebut bertujuan untuk menggali bagaimana efek faktor produksi terhadap produktivitas tenaga kerja sebelum pandemi maupun di masa pandemi serta keterkaitan antara kedua sektor tersebut. Penelitian ini diharapkan mampu memnjadi acuan bagi penelitian lainnya yang berhubungan dengan produktivitas tenaga kerja sektoral di masa pandemi serta dapat dikembangkan dengan menggunakan efek spasial.

\subsection{Implikasi Praktis}

Hasil penelitian ini diharapkan mampu memberikan gambaran mengenai sebaran produktivitas tenaga kerja di sektor pertanian dan industri pengolahan sebelum dan saat pandemi Covid-19 serta variabel makri yang mempengaruhinya. Dari hasil tersebut dapat menjadi refrensi bagi pemerintah daerah maupun stakeholder terkait dalam menyusun strategi dan kebijakan terhadap pendidikan, kesehatan, investasi serta tingkat upah dalam mendorong produktivitas tenaga kerja di sektor pertanian dan industri pengolahan khususnya di masa pandemi Covid-19.

\subsection{Saran}

Peningkatan kualitas SDM, maupun sarana produksi lainnya baik di sektor pertanian maupun industri pengolahan perlu terus ditingkatkan terutama pada kawasan sentra demi peningkatan produktivitas tenaga kerja. Selain itu, besaran UMK harus selalu diperbaharui dan disesuaikan dengan perkembangan makro ekonomi. Dimensi kesehatan juga perlu mendapat perhatian lebih seperti memberikan pos anggaran yang lebih lagi, apalagi kondisi pandemi yang menurunkan kualitas kesehatan masyarakat. Diharapkan dengan besarnya pos anggaran kesehatan maka masyarakat lebih sehat dan lebih produktif serta dapat mengantisipasi waktu produktif yang terbuang karena sakit.

\section{Referensi}

Badan Pusat Statistik. (2020). Keadaan Ketenagakerjaan Sumatera Utara Februari 2020. 19(28), 1-15. https://sumut.bps.go.id/pressrelease/2021/05/05/848/februari-2021-tingkat-pengangguran-terbuka--tpt--sebesar-6-01-persen.html 
BAPPENAS. (2020). Pembangunan Ekonomi Inklusif. http://inklusif.bappenas.go.id/

BPS. (2021). Katalog BPS: 9199007 INDONESIA 2021 LAPORAN PEREKONOMIAN DAMPAK ADANYA PROGRAM PEMULIHAN EKONOMI NASIONAL (PEN) TERHADAP PEREKONOMIAN INDONESIA DI MASA PANDEMI. 188.

BPS Provinsi Sumatera Utara. (2020). Tinjauan PDRB Kabupaten/Kota se-Sumatera Utara Menurut Lapangan Usaha 2020.

BPS Provinsi Sumatera Utara. (2021). Provinsi Sumatera Utara Dalam Angka Tahun 2021. In Provinsi Sumatera Utara Dalam Angka 2021.

BPS Sumatera Utara. (2021). Jumlah pengangguran (000) dan Tingkat Pengangguran Terbuka (TPT) Provinsi Sumatera Utara Semesteran 2019-2021.

Fadillah, A., Ginting, R., \& Lubis, I. (2020). Analisis Determinan Produktivitas Tenaga Kerja di Indonesia. Jurnal Penelitian Pendidikan Sosial Humaniora, 5(2), 142-150.

Hellen, H., Mintarti, S., \& Fitriadi, F. (2018). Pengaruh investasi dan tenaga kerja serta pengeluaran pemerintah terhadap pertumbuhan ekonomi serta kesempatan kerja. Inovasi, 13(1), 28. https://doi.org/10.29264/jinv.v13i1.2490

ILO. (2021). Statistics on Labour Productivity. https://ilostat.ilo.org/topics/labourproductivity/

Montgomery, D. C., Peck, E. A., \& Vining, G. G. (2012). Introduction to Linear Regression Analysis (Fourth). Wiley.

Oktavia, A., Zulfanetti, Z., \& Yulmardi, Y. (2017). Analisis produktivitas tenaga kerja sektor pertanian di Sumatera. Jurnal Paradigma Ekonomika, 12(2), 49-56. https://doi.org/10.22437/paradigma.v12i2.3940

Raynaldhi, Y. (2016). Pengaruh Faktor Penentu Indeks Pembangunan Manusia terhadap Pertumbuhan Ekonomi Jawa Timur. Jurnal Ilmiah Mahasiswa FEB, 4(2).

Sari, R. D. P., \& Oktora, S. I. (2021). Determinan Produktivitas Tenaga Kerja Industri Manufaktur Besar dan Sedang di Pulau Jawa. Jurnal Ekonomi Dan Pembangunan Indonesia, 21(2), 185-203. https://doi.org/10.21002/jepi.v21i2.1298

Simanjuntak, P. (1985). Pengantar Ekonomi Sumber Daya Manusia. Fakultas Ekonomi Universitas Indonesia.

Siregar, I. N. P. (2018). Analisis Peran Sektor Perkebunan Terhadap Perekonomian Sumatera Utara. Jurnal Ekonomi Pendidikan, 6(4), 34-41.

Sukirno, S. (2021). Pengantar Teori Mikroekonomi. PT. RajaGrafindo Persada.

Sumarlin, \& Sirojuzilam. (2010). Analisis Hubungan Tingkat Upah Tinggi Terhadap Produktivitas di Indonesia. Jurnal Mepa Ekonomi USU.

Syafri, S. (2012). Teori Akuntansi. Rajawali Press.

Trisnu, C. G. S. P., \& Sudiana, I. K. (2019). Pengaruh Pertumbuhan Penduduk, Pengangguran, dan Pendidikan terhadap Tingkat Kemisikinan Kabupaten/Kota Provinsi Bali. E-Jurnal EP Unud, 8(11), 2622-2655. http://download.garuda.ristekdikti.go.id/article.php?article=1357259\&val=981\&titl e=Pengaruh Pertumbuhan Penduduk Pengangguran dan Pendidikan terhadap Tingkat Kemiskinan Kabupatenkota Provinsi Bali 
Wulandari, H. (2018). Disparitas dan Konvergensi Regional Produktivitas Tenaga Kerja Sektor Industri Manufaktur Provinsi Jawa Barat Tahun 2008-2015 (Pendekatan Panel Dinamis). Politeknik Statistika STIS.

Yektiningsih, E. (2018). Analisis Indeks Pembangunan Manusia (Ipm) Kabupaten Pacitan Tahun 2018. Jurnal Ilmiah Sosio Agribis, 18(2), 32-50. https://doi.org/10.30742/jisa.v18i2.528. 